ISSN 25980580

Bioscientia Medicina Volume 4, Issue 1, Page No: 11-18

Available online : www.bioscmed.com

Bio Sc Med 4(1):11-18

\title{
Polymorphism E23K KCNJ11 Gen as a Risk Factor of Diabetes Mellitus in Serawai Tribe Of Bengkulu
}

\author{
Raden Sunita $^{1 \#}$, Sahidan Sahidan ${ }^{1}$, Rachmat Hidayat $^{2}$, Resva Meinisasti $^{1}$ \\ ${ }^{1}$ Polytechnic of Health,Bengkulu, Indonesia \\ ${ }^{2}$ Department of Biology, Faculty of Medicine, Universitas Sriwijaya, Indonesia
}

${ }^{\#}$ Corresponding author E-mail: sunita@gmail.com

Received : October $22^{\text {nd }} 2019$

Accepted : December $25^{\text {th }} 2019$

\begin{abstract}
Background: Type 2 diabetes mellitus (T2DM) is a multifactorial disease involving genetic and environmental factors. The E23K KCNJ11 gene polymorphism causes KATP canal overactivity, decreases cell membrane depolarization potential, and decreases insulin secretion. E23K polymorphism of the KCNJ11 gene as a risk factor for T2DM.

Methods: This study is a case-control study. The subjects of the study were 100 people with T2DM patients as a case group (50 people) and Non-DM subjects with families who did not have a history of T2DM as a control group (50 people). Fasting blood glucose (GDP) was analyzed by spectrophotometry and E23K KCNJ11 gene by polymerase chain reaction fragment length polymorphism (PCR-RFLP). Data were analyzed by statistics.

Results: The frequency of AA genotypes in cases was higher than the controls $(12 \%$ and $8 \%)(p=0.001)$. The frequency of A allele in the case was higher than the control (32\% and 18\%) $(\mathrm{p}=0.017)$. The risk of T2DM on AA / GA genotypes was 4.75 times higher in cases than controls $(p=0,000$, OR $4.7595 \%$ CI 2.01-11.24). The risk of T2DM in A allele was 2.14 times higher in cases than in controls $(\mathrm{p}=0.017$, OR 2.14, 95\% CI 1.11-4.15). Conclusion: E23K polymorphism of the KCNJ11 gene as a risk factor for T2DM in Bengkulu Serawai Tribe.
\end{abstract}

Keywords: E23K gene KCNJ11, DMT2, Non-DMT2

\section{Introduction}

Diabetes mellitus (DM) is caused by interactions between genetic factors and the environment. Diabetes mellitus is also closely related to family history, increase in body mass index, and decreased insulin secretion and insulin work. ${ }^{1}$ Globally, DM patients living in cities reach 246 million people and in rural areas, as many as 136 million people. ${ }^{2}$ The increase in the incidence of type 2 diabetes mellitus (T2DM) is a metabolic disease characterized by hyperglycemia due to damage to insulin secretion, insulin action, and/or both. ${ }^{3}$ Insulin is a hormone produced by $\beta$ cells of the islets of Langerhans in the pancreas in response to hyperglycemia and plays a central role in regulating blood glucose. ${ }^{4}$ Chronic hyperglycemia in 
people with T2DM can lead to failure of various organs, especially the eyes, kidneys, nerves, heart, and blood vessels. ${ }^{5}$

The KCNJ11 gene is located on the same chromosome at the locus $11 \mathrm{p} 15.1$ only $4.5 \mathrm{~kb}$ apart, both of these genes work on the potassium canal in pancreatic $\beta$ cells. The KCNJ11 gene functions to regulate insulin secretion. Polymorphism in the KCNJ11 gene can affect the function of the pancreas resulting in changes in activity in the potassium canal. Polymorphism in the KCNJ11 gene resulted in a decrease in potassium canal sensitivity to ATP so that the canal remained open and decreased insulin secretion caused Impaired Glucose Tolerance (IGT) which eventually became T2DM. ${ }^{6}$

Lifestyle changes that are influenced by environmental factors in genetically susceptible groups will cause various diseases, related to genetic factors, one of which is DM disease. Based on the above data, it also indicates that T2DM is still a public health problem in Indonesia, especially in Bengkulu. Ethnic Bengkulu consists of the Serawai, Mukomuko, Pekal, Rejang, Lembak, Basemah, Kaur, Enggano tribes. In this case, the Serawai tribe as a genetic subject of the Potassium gene polymorphism is inwardly rectifying the subfamily channel J member 11 (KCNJ11) DMT2.

\section{Methods}

The research design is a case-control study. The subjects of the study were 50 cases recruited from Bengkulu DMT2 patients and 50 controls recruited from the academic community and Bengkulu Health Polytechnic students. Cases fulfilling the inclusion criteria are healthy men or women aged between 19-39 years, have families suffering from DMT2 (father / mother-grandfather / grandmother) and Serawai tribe, while controls do not have families suffering from DMT2 (father / mother-grandfather / grandmother) and Serawai. Exclusion criteria were detected by DM with fasting blood glucose (GDP) $\geq 126 \mathrm{mg} / \mathrm{dL}$, obesity (BMI $\geq 25 \mathrm{~kg} / \mathrm{m} 2$ ), hypertension (systolic BP) TD $140 \mathrm{mmHg}$, blood pressure (TD) diastolic $\geq 90 \mathrm{mmHg}$ ) and get pregnant.

GDP levels were analyzed by spectrophotometry of the glucose oxidase-p-amino phenazone method (GOD-PAP). DNA isolation using Promega's Wizard Genomic DNA Purification Kit. The E23K polymorphism of the KCNJ11 gene was analyzed by polymerase chain reaction fragment length polymorphism (PCR-RFLP). Amplification of DNA fragments flanking the position of the E23K KCNJ11 gene with primers: forward primers 5'-CCA CCG 
ISSN 25980580

AGA CTC TGC A-3 'and reverse primers 5'-CTG GGC ACG GTA CCT-3' GCG. Reaction PCR $30 \mu \mathrm{L}$ consisting of: $2 \mu \mathrm{L}$ DNA, $15 \mu \mathrm{L}$ PCR master mix (2x PCR buffer, $150 \mathrm{mM}$ dNTP, and $0.5 \mathrm{U}$ Taq DNA polymerase), $2 \mu \mathrm{L}$ primer ( $1 \mu \mathrm{L}$ forward primer and $1 \mu \mathrm{L}$ reverse primer) and $11 \mu \mathrm{L}$ aquades.

PCR cycle temperature conditions: (1) Initial denaturation for 7 minutes at $94 \mathrm{oC}$, followed by 35 PCR cycles: (2) denaturation at 94oC 1 minute; (3) annealing at $63 \mathrm{oC} 1$ minute; (4) extension at $72 \mathrm{oC} 1$ minute; (5) final extension 7 minutes at $72 \mathrm{oC}$; (6) cooling to $4 \mathrm{oC}$. PCR runs for 2 hours 16 minutes.

Cutting PCR products with restriction enzymes (RFLP): $4 \mu \mathrm{L}$ PCR products plus 1.0 $\mu \mathrm{L}$ NE buffer, $0.5 \mu \mathrm{L}$ Ban II (Thermo) enzyme, $4.5 \mu \mathrm{L}$ aquades up to the final volume of 10 $\mu \mathrm{L}$ reaction mixture. The reaction mixture was incubated for 16 hours at $37 \mathrm{oC}$ in an incubator. The reaction was carried out by electrophoresis with $3 \%$ agarose gel (for 45 minutes, 100 volts) and visualized with ethidium bromide. Cutting results were seen under UV light, namely: GG (wild type) genotype had one band (179 bp), GA genotype had three bands (179 bp, $160 \mathrm{bp}$, and $19 \mathrm{bp}$ ) and AA genotype had two bands (160 bp and $19 \mathrm{bp}$ ).

\section{Results}

Genotypic frequency distribution in cases was AA (12\%), GA (48\%) and GG (40\%), while in controls were AA (8\%), GA (16\%) and GG (76\%). There were significant differences in genotypic frequency distribution between cases and controls $(p=0.001)$. The allele frequency distribution in the cases was A (32\%) and G (68\%), while those in the controls were A $(18 \%)$ and $G(82 \%)$. There were significant differences in allele frequency distribution between cases and controls $(\mathrm{p}=0.017)$. Odds ratio test results to determine AA and GA genotypic risk showed a significant relationship between AA and GA genotypes between cases and controls ( $\mathrm{p}=0,000$, OR $4.7595 \%$ IK 2.01-11.24). Likewise, the A allele showed a significant relationship between cases and controls $(\mathrm{p}=0.017$ OR 2.14 95\% IK 1.12-4.15). Genotypic frequency distribution (AA, GA, GG) and alleles (A and G) in cases and controls can be seen in Table 1. 
ISSN 25980580

Table 1. Genotypic frequency distribution (AA, GA, GG) and alleles (A and G)

\begin{tabular}{lcccc}
\hline Variabel & & $\begin{array}{c}\text { Kasus } \\
(\mathrm{n}=50)\end{array}$ & $\begin{array}{c}\text { Kontrol } \\
(\mathrm{n}=50)\end{array}$ & $\begin{array}{c}P \\
\text { OR(CI 95\%) }\end{array}$ \\
\hline Genotip & AA & $6(12 \%)$ & $4(8 \%)$ & $0,001^{*}$ \\
& GA & $24(48 \%)$ & $8(16 \%)$ & \\
& GG & $20(40 \%)$ & $38(76 \%)$ & \\
\hline Genotip & AA_GA & $30(60 \%)$ & $12(24 \%)$ & $0,000^{*}$ \\
& GG & $20(40 \%)$ & $38(76 \%)$ & OR 4,75 \\
& & & & $(2,01-11,24)$ \\
\hline Alel & A & $32(32 \%)$ & $18(18 \%)$ & $0,017 *$ \\
& G & $68(68 \%)$ & $82(82 \%)$ & OR 2,14 \\
& & & & $(1,12-4,15)$ \\
\hline
\end{tabular}

${ }^{*}$ Chi-Square Test

\section{Discussion}

The frequency of genotypes and the E23K polymorphism allele of the KCNJ11 gene in cases and controls in Bengkulu, especially the Serawai tribe varied because of the distribution of different genotypes in homozygotes and heterozygotes. The difference between this research and research in several other countries is the number of samples. The number of samples in research in several other countries is more than the number of samples in this study.

The results of this study are similar to studies in several populations, namely West Asia (Palestine, Israel), East Asia (China, Japan) and Western Europe (Germany) that the AA genotype frequency in T2DM patients is higher than Non-DM. Thus the frequency of AA genotypes shows variations in geography and nation/ethnicity. The frequency of AA genotypes and $\mathrm{A}$ allele higher in a population indicates that the E23K KCNJ11 gene polymorphism increases the risk of T2DM.

The results of this study indicate that the AA genotype frequency in the cases was higher than the controls (12\% and 8\%). The study of the E23K KCNJ11 gene polymorphism in Japan at 889 normal individuals and 906 T2DM patients showed that AA genotypic frequency in T2DM patients was higher than Non-DM (14\% and 12\%), and there was a significant relationship between polymorphism E23K KCNJ11 gene with the risk of developing T2DM ( $p=0.004$, OR $1.32,95 \%$ IK $1.09-1.60){ }^{7-8}$

The results of this study are different from the E23K polymorphism of the KCNJ11 gene in Israel in 843 normal individuals and 573 T2DM patients who showed no significant association between the E23K KCNJ11 gene polymorphism and the risk of T2DM ( $p=0.52$, OR 1.05, 95\% CI 0.90-1.23). ${ }^{9-12}$ The results of this study indicate that the GA genotype frequency in the cases was higher than the controls (48\% and 16\%). These results differ from 
ISSN 25980580

studies in Chinese Hubei, Israel and Shandong China. The results of this study are the same as the E23K study of KCNJ11 genes in Czechoslovakia, Japan, Germany, Beijing and Palestine which show GA genotype frequency in T2DM patients higher than Non-DM. ${ }^{13-16}$

The frequency of GG genotypes in cases is lower than controls. These results are similar to studies in Japan, Germany, Shanghai China, Beijing, Palestine and Yogyakarta, but different from the frequency of GG genotypes in Chinese Hubei and Shandong China showed that in DMT2 patients it was higher than Non-DM (22\% and $15 \%)$ and $(39 \%$ and $35 \%) .{ }^{17-20}$

The E23K polymorphism of the KCNJ11 gene that causes substitution of guanine (G) becomes adenine (A) so that there is a change in the amino acid glutamate (GAG) to lysine (AAG) . The E23K polymorphism of the KCNJ11 gene resulted in changes in the function of potassium canals because it made potassium canals not sensitive to ATP, thus requiring a more significant amount of ATP to close potassium canals and potassium canals remained open. Potassium channels that remain open cause hyperpolarization, resulting in inhibited insulin release. Decreasing insulin secretion will cause a reduction in glucose use by tissues and an increase in liver glucose production, which can lead to hyperglycemia. In prolonged conditions, pancreatic $\beta$ cells are no longer able to produce insulin, resulting in T2DM. The E23K KCNJ11 gene polymorphism causes KATP canal overactivity, decreases the potential of cell membrane depolarization, and decreases insulin secretion. ${ }^{21}$

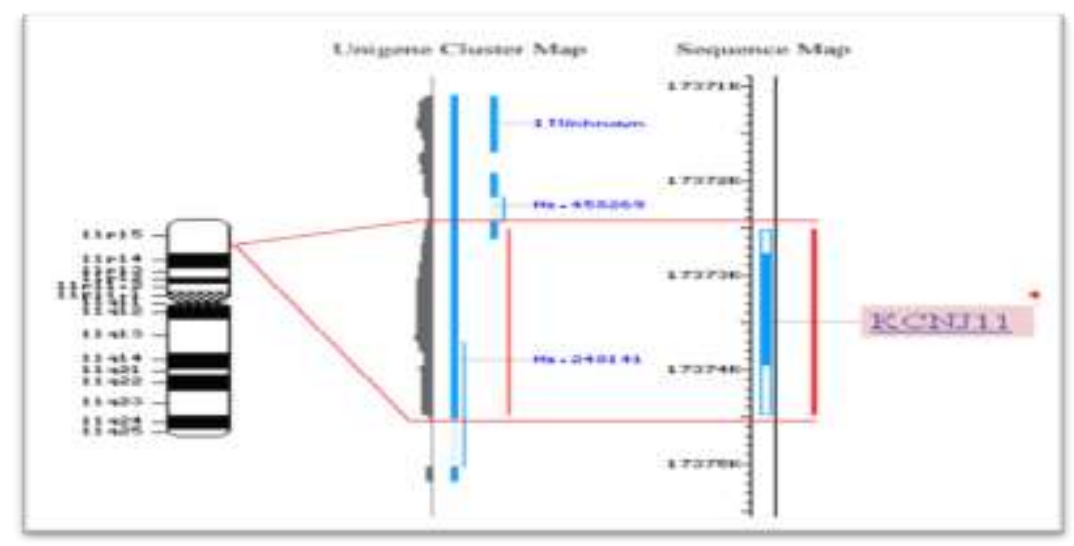

Figure 1. The location of the KCNJ11 gene in the human genome at position 11p15.1 around 17,372-17,375 kb (http://www.ncbi.nlm.nih.gov)

The KCNJ11 gene structure is composed of two transmembrane (TMs) and N-terminal domains and an intracellular C-terminal. The transmembrane helical outer side (TM1) is 
ISSN 25980580

associated with the $\mathrm{N}$-terminal domain (N-domain) by amphipathic alpha-helices, namely a helical slide located perpendicular to the transmembrane. The helical slide position shows its role as the closing and opening of the KATP canal. The Inner helix (TM2) is connected with TM1 through an extracellular connector and a loop consisting of a small helical or selective filter which is responsible for the selective permeability of Potassium ions. The KATP channel in pancreatic $\beta$ cells consists of two subunits: (1) regulatory subunits including subfamily ATPbinding Casettes (ABC) including SUR1, SUR2A and SUR2B and (2) porous canal namely Potassium inward rectifier $6.2\left(\right.$ Kir6.2) / $(\mathrm{KCNJ} 11){ }^{22}$

\section{Conclusion}

It can be concluded that the $\mathrm{E} 23 \mathrm{~K} \mathrm{KCNJ} 11$ gene polymorphism is a DM risk factor in the Bengkulu Serawai Tribe.

\section{References}

1. Abed, A.A., Ayesh, B.M., Hamdona, O.M., 2013. Single nucleotide polymorphism E23K of $K C N J 11$ gene and other risk factors associated with type-2 diabetes mellitus in Gaza. Int.J.Chem. And Life Sci. 02 (04): 1146-1152.

2. Acheson, L.S., Wang, C., Zyzanski, S.J., Lynn, A., Ruffin, M.T., Gramling, R., Rubinstein, W.S., O’neill, S.M., Nease, D.E., 2010. Family history and perceptions about risk and prevention for chronic diseases in primary care: a report from the family healthware ${ }^{\mathrm{TM}}$ impact trial. Genet Med. 12(4): 212-218.

3. American Diabetes Association, 2012. Diagnosis and classification of diabetes mellitus. Diabetes Care. 3 (Suppl.1) 35: S64-71.

4. Badan Penelitian dan Pengembangan Kementerian Kesehatan R.I. 2013. Laporan Riset Kesehatan Dasar (Riskesdas) 2013.

5. Bryan, J., Vila-Carriles, W., Zhao, G., Babenko, A.P., Agular-Bryan, L., 2004. Toward linking structure with function in ATP-sensitive $\mathrm{K}^{+}$channels.Diabetes. 53 (Suppl. 3). S104-112.

6. Cejkova, P., Novota, P., Cerna, M., Kolostova, K., Novakova, D., Kucera, P., Novak, J., Andel, M., Weber, P., Zdarsky, E., 2007. KCNJ11 E23K polymorphism and diabetes mellitus with adult onset in Czech patients. Folia Biol (Praha). 53: 173-175. 
7. Fischer, A., Fischer, E., Ohlig, M.M., Schulze, M., Hoffmann, K., Weickert, M.O., Schueler, R., Osterhoff, M., Pfeiffer, A.F.H., Boeing, H., Spranger, J., 2008.KCNJ11 $\mathrm{E} 23 \mathrm{~K}$ affects diabetes risk and is associated with the disposition index.Diabetes Care. 31: 87-89.

8. Genetic Home References, 2016. Structur of KCNJ11gene.U.S National Library of Medicine.Available from http://www.usa.gov. Akses 10 Oktober 2016.

9. International Diabetes Federation, 2000.Diabetes Atlas2000.International Diabetes Federation (IDF).

10. Li, Y.Y., 2013. The KCNJ11 E23K gene polymorphism and type 2 diabetes mellitus in the Chinese Han population: a meta-analysis of 6,109 subjects. Mol Biol Rep. 40: 141146.

11. Linawati, Y., 2009. Polimorfisme p.R1273R gena Sulfonylurea Receptor-1 (SUR1) sebagai faktor risiko diabetes melitus tipe 2 pada populasi Jawa. (tesis), Pascasarjana Universitas Gadjah Mada.

12. Liu, L.F., Lei, J.J., Liu, H.Y., Zou, Q.J., Sun, Y.H., 2010. Identification of susceptibility gene loci associated with type 2 diabetes. Wuhan Univ J Nat Sci. 15:171-175.

13. Neuman, R.J., Wasson, J., Atzmon, G., Wainstein, J., Yerushalmi, Y., Cohen, J., Barzilai, N., Blech, I., Glaser, B., Permutt, M.A., 2010. Gene-gene interactions lead to higher risk for development of type 2 diabetes in an Ashkenazi Jewish population. PlosOne.5(3):1-6.

14. Nussbaum, R.L., McInnes, R.R., Willard, H.F., 2004. Thompson and thompson genetic in medicine, $6^{\text {th }}$ revised edition. Saunders. Philadelphia. USA.

15. Prabandari, A.S., 2009. Polimorfisme p.E23K gena potassium inwardly-rectifying channel sub family J member 11 (KCNJ11) sebagai faktor risiko diabetes melitus type 2 di Yogyakarta (tesis), Pascasarjana Universitas Gadjah Mada.

16. Proks, P., Ashcroft, F.M., 2008. Modeling $\mathrm{K}_{\mathrm{ATP}}$ channel gating and its regulation. Biophysics and Molecular Biol. 99:7-19.

17. Sakamoto, Y., Inoue, H., Keshavarz, P., Miyawaki, K., Yamaguchi, Y., Moritani, M., Kunika, K., Nakamura, N., Yoshikawa, T., Yasui, N., Shiota, H., Tanahashi, T., Itakura, M., 2007. SNPs in the KCNJ11-ABCC8 gene locus are associated with type 2 diabetes and blood pressure levels in the Japanese population. J Hum Genet.52: 781-793. 
ISSN 25980580

18. Schwanstecher, C., Neugebaeur, B., Schulz, M., Schwanstecher, M., 2002. The common single nucleotide polymorphism E23K in K(IR)6.2 sensitize $\beta$-cell ATPsensitive potassium channels toward activatio through nucleoside diphosphates. Diabetes. 51: 363-367.

19. Wang, F., Han, X.Y., Ren, Q., Zhang, X.Y., Han, L.C., Luo Y.Y., Zhou, X.H., Ji, L.N.,2009.Effect of genetic variants in KCNJ11, ABCC8, PPARG and HNF4A loci on the susceptibility of type 2 diabetes in Chinese Han population.Chin Med J (Engl) 122 (20): 2477-2482.

20. Wang, G.F., Jiang, W.J., Jiang, X.B., Wu, Y.L., Zhang, D.F., 2011. Correlation study of $K C N J 11$ gene E23K polymorphism with type 2 diabetes mellitus. Acta Academiae Medicinae Qingdao Universitatis. 47: 104-107.

21. Weber, M.B., Frank, R.O., Staimez, L.R., Ali, M.K., \& Narayan, K.M.V., 2012. Type 2 diabetes in Asians: prevalence, risk factors, and effectiveness of behavioral intervention at individual and population levels. Annu.Rev.Nutr. 32: 417-439.

22. Zhou, D., Zhang, D., Liu, Y., Zhao, T., Chen, Z.,Liu, Z., Yu, L., Zhang, Z., Xu, H., He, L., 2009. The E23K variation in the KCNJ11 gene is associated with type 2 diabetes in Chinese and East Asian population. J Hum Genet. 54: 